\title{
MENGGALI TOLERANSI BERBASIS LOKAL
}

\author{
Khairul Huda \\ Program Pascasarjana IAIN Imam Bonjol Padang \\ irul_huda@gmail.com \\ Oyondri \\ Guru PAI pada SMA Kabupaten Pelalawan \\ oyon_dri@gmail.com
}

\begin{abstract}
Abstak
Pelaksanaan demokrasi secara utuh dan menyeluruh pasca reformasi telah menciptakan asmofir baru bagi penguatan kembali gagasan puritanisme absolut dalam konteks Indonesia. Kini segmen garapan mereka tidak hanya meliputi wilayah kultural saja, tapi sudah masuk ke wilayah struktural yang lebih luas dan sistematis. Situasi ini mengakibatkan dinamika keberagamaan di Indonesia semakin "rumit" dan mengalami "komplikasi". Sebagai salah satu cara untuk mengimbangi derasnya "arus" Islam kanan yang dalam batas-batas tertentu "mengkhawatirkan" itu, perlu diwariskan kembali suatu model keagamaan yang moderat dan toleran yang terbukti telah mampu membangun suatu tatanan kehidupan masyarakat yang rukun dan harmonis sepanjang perjalanan sejarah bangsa Indonesia
\end{abstract}

Kata kunci: Islam, Melayu, dan Budaya

\section{Pendahuluan}

Ada satu perkembangan yang cukup "mengkhawatirkan" akhir-akhir ini dalam konteks hubungan internal keagamaan di Indonesia, yaitu menguatnya pemikiran dan aksi puritanisme Islam dalam skala yang lebih luas. Puritanisme Islam adalah usaha pemurnian ajaran Islam lewat pengambilan lansung dari sumbersumber utamanya, al-Quran dan Hadits (Malik dan Ibrahim, 1998)

Secara historis, gerakan Islam puritan ini, sering kali dinisbahkan pada gerakan Paderi di Sumatra pada awal abad ke-19 dan kemudian diikuti oleh trio pembaharu pada awal abad ke-20, yaitu Muhammadiyah, Al-Irsyad, dan Persatuan Islam. Perbedaan penampilan dan sasaran garapan ketiga gerakan itu, tidak menghalangi kita untuk menarik suatu benang merah yang menjadi ciri utama dari gerakan-gerakan purifikasi.

Benang merah itu ialah
perlawanannya terhadap tradisi dan
kepercayaan masyarakat yang koruptif
dan menyimpang, serta seruannya untuk


kembali kepada ajaran yang murni (Syafiq A. Mughni, 2001: 5).

Para puritan menampilkan tematema yang menjadi acuan gerakan purifikasi. Di antara tema-tema itu ialah: pertama, bahwa perilaku bid'ah telah melanda umat, sehingga agama yang mereka anut bukan merupakan Islam yang benar dan murni; kedua, bid'ah itu mungkin terjadi akibat penyalahgunaan kekuasaan tokoh-tokoh agama atau akibat pengaruh-pengaruh non-Islam yang secara tidak sengaja mempengaruhi pikiran umat Islam; ketiga, sebagai jalan keluar dari keadaan itu, Islam harus dibersihkan dari semua perilaku itu dengan jalan "kembali kepada Al-Qur'an dan Sunnah"; keempat, tipe ideal dari masyarakat yang dijadikan sebagai rujukan beragama secara murni ialah generasi salaf, yaitu mereka yang hidup pada abad-abad pertama Islam.

Dalam dekade 90-an, situasinya agak sedikit mereda. Hal ini dikarenakan sebagian besar umat di Indonesia mulai sepakat untuk menghentikan pertikaian dan mengalihkan perhatian mereka kepada isu-isu keislaman yang lebih besar dan penting daripada hanya sekedar perdebatan ideologis yang tak pernah berujung. Ditambah lagi, pengaruh iklim pemerintahan orde baru sebelumnya yang sangat menekankan pada persoalan ketahanan dan keamanan masyarakat yang mengedepankan pendekatan represif.
Namun, pada perkembangan selanjutnya, pasca tumbangnya Orde Baru, seiring dengan perubahan sistem ketatanegaraan dan pemerintahan dari sentralistik ke desentralistik (otonomi daerah), kelompok-kelompok puritan menemukan ruang kembali untuk memasarkan ideologinya. Tapi bila diamati secara lebih dalam lagi, kali ini mereka tidak hanya mengedepankan pendekatan kultural (Affandi:1996), namun sudah masuk ke wilayah struktural secara tersistematis. Sistem demokrasi memungkinkan mereka untuk tampil secara vulgar, dan bahkan aksi sebagian mereka sudah sampai pada tingkatan represif dan anarkhis.

Di tengah menggelindingnya pemikiran dan aksi puritanisme-absolut dalam konteks kekinian di Indonesia, adalah penting untuk merevitalisasi spirit Islam tradisionalis yang sudah terbukti mampu menampilkan model keberagamaan yang elegan, moderat dan toleran sehingga masyarakat yang beragama tidak merasa tercerabut dari akar budayanya dan bisa menerima Islam secara sadar dan sepenuh hati.

Islam dan Adat: Dua Variabel yang Berbeda

Kata Islam secara bahasa terambil dari kata aslama-yuslimu-islaman yang memiliki banyak arti; pertama menyerahkan sesuatu, menyerahkan diri pada kekuasaan orang lain, meninggalkan orang di bawah kekuasaan orang lain, meninggalkan (seseorang) bersama 
(musuhnya), berserah diri kepada Tuhan; kedua membayar di muka, seperti dalam kalimat aslama fi al-tha'am. Ketiga, sama dengan kata istaslama yang berarti menyerah, menyerahkan diri, pasrah dan memasuki perdamaian. Sedangkan menurut istilah, Islam adalah ungkapan kerendahan hati dan ketaatan secara lahiriah kepada hukum Tuhan serta mewajibkan diri untuk melakukan atau mengatakan apa yang telah dilakukan dan dikatakan oleh Nabi saw (Rahmat, 2006).

Quraish Shihab (2000) ketika menafsirkan surat Ali Imran ayat 85 yang dimaksud dengan kata "Islam" dalam ayat tersebut adalah agama para Nabi terdahulu tidak hanya terbatas hanya pada risalah yang dibawa Nabi Muhammad saw saja. Tetapi Islam adalah ketundukan makhluk kepada Tuhan Yang Maha Esa dalam ajaran yang dibawa oleh para rasul, yang didukung oleh mukjizat dan bukti-bukti yang meyakinkan. Hanya saja kata "Islam" untuk ajaran para nabi yang lalu merupakan sifat, sedangkan ummat Nabi Muhammad saw. Memiliki keistimewaan dari sisi kesinambungan sifat itu bagi agama umat Muhammad, sekaligus menjadi tanda dan nama baginya.

Dari uraian sebelumnya bisa dipahami Islam merupakan agama yang diturunkan Allah swt melalui Nabi-Nya yang bersifat transenden (tinggi). Di dalamnya berisi nilai-nilai ideal-universal, seperti nilai ketuhanan, kemanusiaan, kebajikan dan keadilan. Dalam pengertian lain, agama menuntun manusia agar hidup bertuhan (tidak ateis), berprikemanusiaan, berbuat kebajikan dan keadilan.

Sedangkan adat menurut Koentjoroningrat (2002), merupakan unsur dari kebudayaan yang secara khusus terdiri dari nilai-nilai, pandangan hidup, cita-cita, norma-norma, hukum, pengetahuan dan keyakinan yang hidup dalam alam pikiran sebagian besar dari warga suatu masyarakat yang berfungsi sebagai pedoman yang memberikan arah dan orientasi kepada kehidupan para warga masyarakat.

Adat itu terbentuk hasil dari proses interaksi antara manusia dan manusia, manusia dan lingkungannya serta manusia dengan alam semesta. Kemudian diformulasikan menjadi rumusan-rumusan, biasanya berbentuk redaksi verbalis, yang di sepakati secara kolektif dalam sebuah komunitas tertentu

Pada saat Islam itu "didaratkan" atau "membumi" di kawasan nusantara, ia sudah pasti bersentuhan dengan budaya (tradisi) lokal penduduk setempat. Karena itu tidak bisa dinafikan secara sosiologis terjadinya upaya-upaya kontak sosial dan komunikasi antara kedua variabel yang berbeda tersebut.

Secara kategorik, M.B. Hooker (1983) membedakan nilai budaya lokal itu dikonstruksi berasaskan nilai filosofis 
pribumi dan sumber-sumber India sedangkan nilai Islam berdasarkan nilai wahyu yang bersifat universal:

The verse is written in the Arabic language, its premises are expressed in terms of the Arabic culture of the Middle East and its raison d'etre originates in Revelation. The cultural realities of South-East Asia, on the other hand, include the Malay and other languages; and pre-Islamic explanations of the world order deriving either from indigenous philosophies or from Indian sources. The purpose of this introduction is to describe the structure of the accommodation between the Middle-East derived from of Islam and the culture(s) of South-East Asia (Hooker, 1983:2).

Proses akhir dari upaya kompromistis dan akomodasi itu menyebabkan terjadinya "persebatian" antara Islam dan budaya yang melahirkan corak keberagamaan yang khas dan unik. Suatu corak yang mengakomodir adat dalam praktek keagamaan atau paling tidak menjadikan budaya sebagai "media atau sarana" untuk menyampaikan pesan-pesan Islam. Penomena seperti ini hampir terjadi di semua wilayah di kawasan nusantara.

Yang paling menarik proses persebatian antara Islam dan tradisi lokal, atau dengan istilah lain Islamisasi adat, itu terjadi bisa dikatakan tanpa konflik yang siqnifikan. Islam bisa diterima dengan senang hati penduduk pribumi tanpa ada hambatan-hambatan yang bersifat kultural.
Padahal secara sosiologis, seperti dikemukakan oleh Soejono Soekanto (2006) sistem kepercayaan seperti ideologi, falsafah hidup dan lain-lain adalah unsur kebudayaan yang sulit diterima oleh suatu masyarakat. Karena itu, sifat dasar dan karakteristik dari suatu masyarakat senantiasa bersifat tertutup dan mencurigai ideologi asing yang masuk dalam komunitasnya. Proses penerimaan ideologi baru di suatu masyarakat pasti akan menimbulkan gesekan-gesekan sosial meskipun terjadi dalam intensitas yang kecil.

Penerimaan Islam secara damai di nusantara ini, menurut Alwi Shihab (2001) tidak terlepas dari peran tokohtokoh tasawuf. Keberhasilan para sufi dalam berdakwah terutama sekali ditentukan oleh pergaulan dengan kelompok-kelompok masyarakat dari rakyat kecil dan keteladanan yang melambangkan puncak kesalehan dan ketakwaan dengan memberikan pelayanan-pelayanan sosial, sumbangan, dan bantuan dalam rangka kebersamaan dan rasa persaudaraan murni. Dengan keteladanan ini, penduduk menjadi simpati dan memeluk Islam serta mengakibatkan tersebarnya Islam di seluruh penjuru Indonesia sehingga negeri ini terbebas dari animisme dan syirik.

Antony Reid (2004) menyebutkan salah satu faktor utama yang menyebabkan Islam diterima secara massif di nusantara karena Islam 
mengusung ide Teologi Universal. Masyarakat pribumi pada waktu itu menganut teologi animisme yang bersifat lokalistik, di mana roh nenek moyang memiliki keterbatasan teritorial dalam memberikan perlindungan dan keamanan kepada para penganutnya.

Menurt Bahtiar (2007), animisme berasal dari bahasa Latin, anima yang berarti jiwa atau roh. Bagi masyarakat primitif, semua alam dipenuhi oleh rohroh yang tidak terhingga jumlahnya, tidak saja manusia atau binatang, tetapi juga benda-benda yang tidak hidup juga memiliki roh, seperti tulang atau batu. Jadi, animisme adalah paham tentang semua benda, baik bernyawa atau tidak bernyawa memiliki jiwa atau roh.

Kehadiran Islam mampu memberikan jawaban atas kekhawatiran dan ketakutan mereka terutama sekali pada saat mereka bepergian meninggalkan kampung halaman (Reid, 2004). Tambahan pula kekuatan mistik Islam yang dimanifestasikan oleh para sufi mampu mengalahkan kekuatan mistik lokal. Dan jejak-jejak mistik Islam itu masih berkembang sampai saat ini khususnya di kalangan masyarakat tradisional terutama sekali dalam praktek-praktek terapi psikis dan pengobatan.

Terlepas dari semua itu, percepatan penerimaan Islam lebih disebabkan oleh pendekatan dakwah yang tidak memarginalkan adat dan tradisi. Para sufi yang hadir di tengah- tengah masyarakat bersikap arif dan santun, mereka tidak menyerang budaya dan adat istiadat setempat; tidak ada statemen provokatif seperti "sesat", "kafir", "bid'ah", "khurafat" dan atau yang senada dengan itu. Simbol-simbol dan nilai-nilai kearifan lokal (local wisdom) tetap dipertahankan akan tetapi diberi muatan Islam. Sehingga orang-orang yang memeluk Islam pada waktu itu tidak merasa kehilangan identitas budayanya. Ini merupakan suatu strategi dakwah yang bijak, cerdas dan bernas.

Sterotip Periferal dan Puritanisme Absolut

Setelah finalisasi model keberagamaan yang sangat pas dalam konteks Indonesia dengan pluralitas budayanya sebagaimana disebut sebelumnya, pada perkembangan berikutnya muncul sterotip negatif yang menyatakan bahwa Islam di Indonesia adalah "Islam Periferal".

Azra (1999) menyebutkan bahwa Islam periferal adalah Islam pinggiran, Islam yang jauh dari bentuk "asli" yang terdapat dan berkembang di Timur Tengah. Dengan kata lain Islam di Asia Tenggara bukanlah "Islam yang sebenarnya" sebagaimana berkembang dan ditemukan di Timur Tengah. Islam Asia Tenggara dalam pandangan ini, adalah Islam yang berkembang dengan sendirinya, bercampur baur dengan dan didominasi oleh budaya dan sistem kepercayaan lokal, yang tak jarang tidak sesuai dengan ajaran Islam. Inti 
pandangan ini adalah bahwa "Islam sebenarnya" hanyalah Islam Timur Tengah, atau lebih sempit lagi, Islam Arab, bukan Islam di Asia Tenggara, atau di wilayah-wilayah lain, seperti di Asia Selatan atau Afrika

Kesimpulan ini diambil setelah dilakukan pengamatan ternyata praktek Islam yang ada di kawasan nusantara dipandang telah menyimpang dari great tradition (tradisi besar) yang berpusat di Timur Tengah. Praktek Islam di nusantara kental dengan nuansa mitologis, klenik dan sinkretik. Banyak kemudian muncul hipotesis absurd yang mendiskripsikan seolah-olah Islam tidak berhasil memberikan pengaruh yang siqnifikan terhadap sistem kepercayaan dan budaya lokal. Dan dalam sistem sosial masyarakat, dinilai yang paling menonjol sebenarnya adalah kekuatan adat sementara Islam hanya merupakan unsur terkecil di dalamnya.

Ilmuwan Barat yang mengkaji Islam awal banyak yang sependapat dengan kesimpulan di atas. Di antaranya London berpendapat bahwa Islam di Nusantara hanyalah lapisan tipis di atas kebudayaan lokal.

Senada dengan London, Van Leur menyatakan bahwa Islam di nusantara merupakan lapisan tipis yang mudah mengelupas dalam timbunan budaya setempat. Tak cukup sampai disitu, Van Leur menambahkan pendapatnya bahwa terhadap Indonesia, Islam tidak membawa pembaruan sepotongpun ke tingkat perkembangan lebih tinggi, baik secara sosial, ekonomi maupun pada dataran negara dan perdagangan.

Selanjutnya bagi Winstedt, pengaruh apapun yang ditanamkan Islam sangat terbatas dan itupun sudah bercampur aduk dengan kepercayaan Hindu-Budha (Azra, 1999).

Pendapat-pendapat di atas disanggah dengan tegas oleh Naquib alAttas yang menyatakan filsafat agama Hindu tidak mempengaruhi masyarakat Melayu-Indonesia, dan mereka yang berpendapat bahwa filsafat Hindu itu membawa pengaruh yang mendalam terlalu berlebih-lebihan.

Melayu-Indonesia lebih cenderung kepada hal-hal yang bersifat seni dari filsafat: mereka tidak mampu merangkum kehalusan metafisika Hindu, ataupun dengan sengaja dan oleh sebab bawaan dirinya, mengabaikan filsafat dan menuntut hanya hal-hal yang sederhana untuk disesuaikan dengan kondisi jiwanya.

Lebih lanjut al-Attas menambahkan pengaruh Hindu hanya terbatas pada kelompok bangsawan, masyarakat Melayu-Indonesia sebenarnya secara keseluruhan bukanlah masyarakat Hindu. Kelompok Bangsawan tidak dapat pula dikatakan benar-benar memahami ajaran-ajaran murni yang terkandung dalam filsafat Hindu asli. 
Mereka hanya mementingkan halhal yang berkaitan dengan upacara serta ajaran-ajaran yang membesarkan keagungan dewa-dewa bagi kepentingan mereka sendiri sebagai penjelmaan dari dewa-dewa itu.

$$
\text { Al-Attas (1984) lebih lanjut }
$$
menunjukan bukti akan pengaruh Islam yang mengesankan ada dalam perkembangan kesusastraan nusantara. Meskipun kesusastraan Hindu sudah berkembang jauh sebelum kedatangan Islam, akan tetapi sastra Hindu lebih bercorak estetis yang kental dengan mitologis. Sementara sastra Islam sudah menggambarkan suatu corak intelektualisme yang tinggi.

Masih dalam konteks yang sama, Azyumardi Azra (1994) berhasil melacak ada jaringan intelektual antara ulama Timur Tengah dan Kepulauan Nusantara pada abad XVII dan XVIII.

Lebih spesifik lagi, di dunia Melayu-Nusantara telah terjadi semacam formulasi budaya yang menunjukkan betapa Islam mampu memberi "ruh" terhadap sistem budaya lokal sehingga menjadi satu kesatuan yang tak terpisahkan satu dan lainnya. Formulasi itu tergambar dalam satu statemen adat yang populer "Adat bersendikan Syara', Syara' bersendikan Kitabullah".

Statemen itu menunjukan Islam telah menjadi sumber inspirasi dan motivasi dalam bersikap dan bertingkah laku bagi komunitas Melayu. Selain itu,
Hussin Mutalib (1996) menyebutkan Islam bukan hanya merupakan keyakinan bagi komunitas Melayu, Ia juga menjadi salah satu landasan utama yang mendasari identitas mereka. Islam dan identitas Melayu memiliki hubungan interkoneksi yang saling terkait satu sama lainnya sehingga menjadi Melayu bisa diidentifikasi sebagai Muslim.

Arus kritisisme terhadap Islam Adat berikutnya muncul pada awal abad 20 melalui gerakan puritanisme yang dibawa oleh pelajar-pelajar Islam yang kembali dari studi di Timur Tengah. Mereka melihat praktek-praktek keagamaan di tanah air sudah menyimpang dari ajaran al-Quran dan Sunah, karena itu perlu diluruskan dan dikembalikan kepada ajaran semula.

Ide "Pembaruan Islam" yang diusung oleh kelompok ini, bila ditelusuri lebih jauh, diinspirasi oleh gagasan pembaruan yang ditawarkan oleh Muhammad Bin Abdul Wahab yang berasal dari Arab Saudi. Isu sentral dalam pembaruan yang mereka lakukan adalah pemurnian aqidah (tauhid) dari noda syirik.

Abdul Wahab sendiri lahir di Uyanina, kota kecil di Najid. Nama ayahnya, yg kebetulan adalah ulama Hamabalit yg tidak terlalu setuju dgn ajaran puteranya, digunakan bagi alirannya, Wahabisme. Wahabi adalah sebuah julukan di Arabia; bangsa Arab sendiri menamakan diri Muwabhidun atau monotheis, karena mereka percaya dan 
mempraktekkan monotheisme dalam bentuk yang paling murni. Ia mengikuti kurikulum studi-studi Islam dan sangat suka dengan ajaran Ibnu Taymiyah di Medinah, tempat ia tinggal utk beberapa lama.

Setelah kematian ayahnya di tahun 1740, ia memulai menyiarkan doktrindoktrinnya. Ia membangkangi sistim menyajikan puja-puja kepada manusia dan kuburan mereka. Ia melawan aliran mistik karena dianggap tidak peduli dgn hukum nabi. Pemujaan kpd para tokoh suci dianggap sbg penghujadan. Ia tidak mengakui otoritas manusia $\mathrm{dlm}$ bentuk apapun dan ia berkotbah bagi diberlakukannya kembali dua sumber Islam, yaitu "al-Qur'an dan Sunnah Nabi”.

Lebih lanjut, dia menyebutkan bahwa, "Kau punya bukunya (al-Quran) dan sunnah, pelajari kata-kata Allah dan bertindak sesuai dgnnya, bahkan kalau mayoritas tidak setuju denganmu." Ia menjabarkan semua keterangan dalam bentuk exegesis dan jurisprudensi dan patuh pada setiap kata secara lahiriah dalam alQur'an \& al-Hadith. Ia menolak semua inovasi utk mengadaptasi Islam sesuai dengan jaman yg terus berubah dan menyatakan perang melawan segala kelonggaran aturan dan menuntut puritanisme primitif.

Kelompok ini tampil di tengahtengah masyarakat dengan melakukan perlawanan secara terbuka terhadap Islam Adat. Karena pendekatan mereka yang terlalu ekstrim dan radikal, tidak jarang di beberapa tempat mendapatkan serangan balik dari kelompok adat.

Selain doktrin jihad, terminologi kafir juka sering kali memunculkan pemahaman yang bisa mendorong seseorang untuk memerangi atau bahkan membunuh orang atau pihak lain. Sejarah Islam telah mencatat bagaimana perkembangan politik Islam telah diwarnai oleh saling serang antara sesama umat Islam dimana masingmasing merasa "direstui" oleh agama karena membela agama Allah dari orangorang kafir.

Kaum khawarij misalnya, dengan mendasarkan pendapatnya pada firman Allah: "barang siapa yang menghukumi (sesuatu) tidak dengan apa yang telab Allah turunkan (al-Qur"an), maka mereka termasuk orang-orang yang kufr" mereka menganggap bahwa tindakan yang dilakukan oleh Ali ibn Abî Tâlib dengan melakukan arbitrase (perjanjian damai) adalah menyimpang dari ketentuan Allah dan dihukumi sebagai tindakan kufr15. Atas dasar ini, memerangi Ali dan Muawiyah adalah sebuah tindakan sah karena mereka termasuk kelompok yang halal darahnya (kafir)

Betulkah praktek keagamaan yang mengakomodir adat itu sepenuhnya menyimpang dari ajaran Islam? tidaklah demikian, simbol adat (tradisi) yang diadopsi oleh Islam itu sebenarnya sudah 
kehilangan nilai. Yang ada hanyalah nilainilai Islam.

Jalan ini sebenarnya ditempuh, sebagaimana disebutkan sebelumnya, sebagai upaya akomodasi adat agar mereka yang memeluk Islam tidak merasa kehilangan entitas budayanya, itupun setelah melakukan penyaringanpenyaringan secara selektif.

Dalam tradisi besar Islam, penomena seperti ini juga terjadi. Lagipula secara teoretis, metodologi hukum Islam memberikan ruang bagi tradisi, atau diistilahkan dengan 'urf, untuk dijadikan referensi dalam menetapkan hukum.

Menurut al-Zuhaili (2006), Ulama sepakat bahwa 'urf (tradisi) adalah dalil atau sumber hukum Islam, bahkan Mazhab Hanafiah dan Malikiah lebih memperluasnya sampai kepada penetapan hukum praktis, pemahaman teks-teks syariat, menjelaskan hukumhukum fiqih yang berbeda dalam wilayah ibadah, muamalat, ahw al-Syahsiyah, sanksi hukum, dan hubungan eksternal.

Ruang gerak Islam sebenarnya tidaklah sesempit sebagaimana dipahami puritanisme. Tradisi Islam sangat terbuka menerima praktek-praktek baru yang sejalan dengan nilai-nilai Islam (alZuhaili, 2006).

Hal ini, sebagaimana yang disebutkan dalam sebuah riwayat dari ibn Mas'ud yang artinya "apa-apa yang dianggap baik oleh orang Muslim, maka
Allah swt menganggapnya sebagai kebaikan, apa-apa yang dianggap buruk oleh orang Muslim, maka Allah swt menganggapnya sebagai keburukan" (alZuhaili, 2006).

Islam juga sangat mengapresiasi upaya seseorang yang memprakarsai suatu kebajikan dengan memberinya pahala secara berlipat ganda atas prakarsanya dan dari orang yang mempraktekan gagasannya tanpa mengurangi nilai pahalanya sedikitpun.

Sebagaimana sebuah hadits yang menyebutkan "Siapa yang memprakarsai suatu kebajikan, maka ia akan memperoleh pabala dan pabala orang yang mengikutinya tanpa mengurangi nilai pabalanya, siapa yang memprakarsai suatu keburukan, maka ia akan mendapat dosa dan dosa orang-orang yang mengikutinya” (H.R.Muslim).

Sampai di sini, adalah suatu sikap yang tidak adil dan tidak bijak gagasan puritanisme yang mengklaim dan menghakimi bahwa praktek Islam adat telah menyimpang dari ajaran Islam yang murni.

\section{Demokrasi Versus Puritanisme}

Pada awalnya gerakan puritan hanya fokus pada isu-isu keagamaan, lebih spesifik lagi pada masalah teologis dan praktek-praktek ibadah. Akan tetapi, memasuki abad 21, gerakan ini sudah menyentuh wilayah sosial yang lebih luas dan politik. 
Sebagian mereka mulai menggugat tatanan demokrasi yang dinilai tidak mampu mengakomodir kepentingan dan aspirasi umat Islam. tambahan lagi, sistem dan praktek demokrasi sepenuhnya mengadopsi model Barat. Mereka menilai sistem demokrasi sebagai sistem sekuler dan dianggap sudah gagal, karenanya mereka berupaya memperjuangkan syariat Islam untuk dijadikan sistem politik alternatif.

Perjuangan politik kelompok kanan ini didasarkan pada pandangan bahwa syariat Islam tidak hanya menyentuh wilayah transenden saja tapi juga wilayah profan. Sesuai dengan prinsip "Islam Kaffah", adalah merupakan kewajiban secara mutlak untuk mengislamkan semua tatanan kehidupan sosial-politik yang sekelur.

Melalui "perubahan sistem kekuasaan", hukum Islam akan bisa ditegakkan secara menyeluruh. Mereka beranggapan bahwa Islam harus menjadi dasar negara; bahwa syariah harus diterima sebagai konstitusi negara; bahwa kedaulatan politik ada di tangan Tuhan; bahwa ide tentang negara-bangsa (nation state) itu bertentangan dengan konsep umat yang tidak mengenal batasanbatasan politik dan daerah; dan bahwa konsep syura (musyawarah) itu berbeda dengan demokrasi yang dikenal dalam diskursus politik modern. Dengan kata lain, dalam konteks pandangan semacam ini, sistem politik modern-di mana banyak negara Islam telah mendasarkan konstruk politiknya- diletakkan dalam posisi yang berlawanan dengan sistem politik Islam (Effendy, 2001).

Secara kronologis bila dilacak, menurut Endang Saifuddin sebenarnya perjuangan politik Islam yang legalistik-formalistik sudah berkembang pada dua dasawarsa pertama Indonesia merdeka. Embrionya muncul pada saat sidang-sidang BPUUPK (Badan Penyelidik Usaha-Usaha Persiapan Kemerdekaan), yang puncaknya terjadi pada sidang tanggal 22 Juni 1945 suatu sistesis dan kompromi politik dapat diwujudkan antara dua pola pemikiran yang berbeda yang kemudian dikenal dengan Piagam Jakarta. Dalam Piagam Jakarta termaktub sila mahkota (pertama); Ketuhanan Yang Maha Esa dengan "Kewajiban Menjalankan Syariat Islam bagi pemeluk-pemeluknya".

Sebenarnya menurut Bahtiar (2001), perjuangan pada dua dasawarsa pertama tersebut menemui kendalakendala yang bersifat kultural maupun struktural, bahkan kenyataan itu telah menimbulkan akibat negatif bagi komunitas politik Islam. Dalam hal ini bisa dikatakan, dalam waktu yang agak lama, politik Islam telah ditempatkan dalam posisi yang tidak menguntungkan, dianggap outsider dalam percaturan politik nasional.

Dalam pemerintahan orde baru, perjuangan politik kelompok kanan menjadi terhenti. Hal ini dikarenakan sistem politik orde baru yang 
meneguhkan ideologi kebangsaan dan nasionalisme sebagai harga mutlak yang harus diimplementasikan dalam kehidupan bernegara dan menutup rapat peluang bagi munculnya ideologiideologi baru, termasuk ideologi Islamlegalistik.

Bahkan, karena terobsesi oleh pembangunan ekonominya, orde baru sangat menekankan masalah-masalah keamanan nasional. Upaya-upaya "perlawanan" terhadap sistem politik yang dijalankan, di bawah UU Subversif akan ditindak secara tegas dan represif. Baru kemudian pada dasawarsa terakhir pemerintahan orba, Islam diberi ruang untuk tampil dalam sistem politik orba, itupun pada wilayah yang sangat terbatas.

Perubahan sistem ketatanegaraan dari sentralistik ke desentralistik (otonomi daerah), di mana pelaksanaan demokrasi bisa dilakukan secara penuh dan terbuka, perjuangan politik syariat Islam kembali mencuat. Kali ini mereka tidak hanya tampil secara kultural, sebagaimana terjadi pada masa orba, tapi juga secara struktural dengan masuk ke lingkaran kekuasaan dan "menyusup" ke organisasi-organisasi sosial yang sangat strategis.

Pada wilayah kultural, sebagian mereka tampil secara vulgar dalam memasarkan ideologinya sedangkan pada tatanan struktural mereka intens memperjuangkan nilai-nilai syariat untuk "dimasukan" dalam rancangan undangundang dan peraturan-peraturan.

\section{Lembaga Pendidikan dan Puritanisme}

Sebagian Lembaga pendidikan, khususnya lembaga pendidikan Islam, disinyalir memiliki hubungan baik langsung maupun tidak langsung dengan gagasan puritanisme. Lembaga pendidikan dipandang sebagai sarana yang paling strategis dan efektif bagi penanaman dan pengembangan ideologi mereka.

Dalam kaitannya dengan proses pembelajaran agama Islam di sebagian madrasah atau sekolah, puritanisme islam itu bisa dibaca dari aspek materi ajar agama Islam cenderung berisikan informasi-informasi yang dikonstruksi berdasarkan pemahaman keagamaan yang sangat harfiah dan rigid.

Teks-teks keagamaan tidak ditafsirkan secara kontekstual dengan merujuk kepada realitas historis dan sosial budaya pada saat teks itu diturunkan (asbab al-nuzul). Pendapatpendapat keagamaan (aqwal al-Ulama) diterima begitu saja tanpa mau mempertanyakan (mengkritisinya) dan materi itu dianggap sebagai sesuatu yang final (bersifat mengikat secara syariat).

Sesuatu yang tadinya merupakan hasil penafsiran (produk pemikiran) diyakini sebagai ideologi (ajaran agama itu sendiri). Sesuatu yang tadinya adalah hasil formulasi dan konstruksi orangorang terdahulu dianggap sebagai 
doktrin yang sakeral yang harus diaplikasikan secara ketat dan tanpa memikirnya lagi (Engineer, 2004).

Sikap seperti ini membuat seseoranng cenderung memiliki pandangan yang sempit dan kaku terhadap agamanya. Yang dinamakan agama menurut mereka hanyalah doktrin yang sejalan dengan alur dan jalan pikiran mereka.

Sedangkan ajaran yang di luar keyakinan mereka dipandang sebagai sesuatu yang menyimpang. Kondisi ini biasanya diperparah lagi dengan terjadinya proses diferensiasi antara yang Islam dan bukan Islam serta sikap keagamaan yang selalu ingin menghakimi pandangan orang lain.

Materi-materi keagamaan itu bisa dikatakan sudah kehilangan aktualitas dan kontekstualitasnya. Sehingga pada saat dihadapkan pada kondisi realitas sosial, ia mengalami benturan sangat tajam yang mengakibatkan terjadinya konflik batiniah dalam diri peserta didik sehingga mempengaruhi sikap dan penampilannya. Dan pada tingkat tertentu akan melahirkan mentalitas "pemberontak".

Dari aspek pendidik, dalam kaitan dengan proses pembelajaran, sebagian pendidik di lembaga pendidikan Islam, meminjam istilah Hasan Hanafi, rata-rata beraliran "kanan" yang memiliki "misi dakwah" untuk cenderung "meng- kanankan" peserta didiknya (dalam Saenong, 2002).

Keberhasilan proses pembelajaran kadang-kadang tidak ditentukan oleh sejauhmana tujuan pendidikan yang sudah dirumuskan tercapai tapi diukur sejauhmana "misi keagamaan" yang diembannya dalam proses pembelajaran itu tercapai; apakah peserta didik itu menjadi "kelompok kanan" atau sebaliknya.

Karakter keagamaan pendidik itu ikut mempengaruhi model pembelajaran yang dikembangkan. Kenyataan menunjukkan, meskipun sudah mengadopsi sistem pembelajaran modern, pola pendidikan keagamaan yang dikembangkan di madrasah atau sekolah masih terkesan konservatif.

Pendekatan yang digunakan bercorak indoktrinasi; dimana materi ajar yang disampaikan harus diterima dan dilaksanakan begitu saja. Tidak ada ruang untuk "mempertanyakannya". Mempertanyakannya dianggap suatu sikap yang kurang pantas.

Pendekatan ini menyebabkan suasana pembelajaran kritis kurang terbangun di lingkungan pendidikan Islam. Peserta didik merasa takut untuk berseberangan dengan gurunya. Karena sikap berseberangan bisa dianggap "nakal" kalau tidak "sesat". Keberagaman Islam kurang mendapat perhatian, pembelajaran lebih menekankan kepada satu model. 
Materi ajar dan model pembelajaran seperti tersebut di atas melahirkan sikap keberagamaan yang fanatik, ekslusif, terlalu kaku dan apriori terhadap keberagaman pada diri peserta didik. Efeknya dalam kehidupan sosial, mereka cenderung tertutup dan menutup diri dari lingkungannya.

Sikap fanatisme kelompok terbentuk dengan sendirinya sehingga dalam banyak kasus mereka membatasi diri dalam pergaulannya. Sementara itu, perbedaan dalam hal keagamaan, dalam batas-batas tertentu, dianggap sebagai "penyimpangan". Dan penyimpangan adalah sesuatu yang berada di luar batas toleransi sehingga secara psikologis mereka tidak siap berbeda karena terbebani oleh hal-hal yang bersifat ideologis.

\section{Revitalisasi Spirit Islam Tradisional}

Dimensi Islam yang ditampilkan oleh puritanisme absolut secara kultural terkesan sangat radikal dan otoriter. Ada nuansa pemaksaan kehendak secara sepihak dan pengkebirian hak-hak otonomi individu untuk berekspresi. Akibatnya, telah terjadi semacam proses penghakiman moral (moral adjugment) secara sewenang-wenang berdasarkan dalih-dalih keagamaan dan tidak tertutup kemungkinan akan berujung pada tindak kekerasan, seperti teror relijius, pemukulan, penghancuran dan tindak anarkhisme lainnya.
Aksi seperti itu dipandang absah menurut mereka karena dibangun atas dasar "pemahaman keagamaan" secara sepihak dan emosional. Bila model Islam seperti ini yang diusung, maka dengan sendirinya akan melahirkan citra buruk bagi Islam yang tinggi sebagai agama damai dan mendatangkan rahmat bagi semesta alam.

Sementara secara struktural, produk-produk yang mereka tawarkan terkesan sektarian dan mengabaikan aspek pluralitas agama dan budaya. Dan dalam batas-batas tertentu, sudah masuk ke wilayah atau mengatur aspek-aspek yang bersifat individual. Cepat atau lambat, penomena keagamaan seperti ini akan menimbulkan situasi yang kontraproduktif baik dalam tatanan kehidupan bermasyarakat, berbangsa dan bernegara.

Melihat perkembangan puritanisme absolut yang sudah semakin "berani" tampil ke permukaan secara vulgar tersebut, demi terwujudnya idealitas Islam yang tinggi dan elegan, maka mesti dilakukan counter terhadap pemikiran dan aksi mereka.

Salah satu konsep yang ditawarkan dalam tulisan ini adalah dengan mewariskan kembali spirit Islam tradisionalis yang dianggap sudah teruji dalam menyikapi dinamika keberagamaan dalam konteks kehidupan berbangsa dan bernegara.

Spirit tersebut antara lain: 
(1) Model keagamaan yang moderat. Moderat (moderate), yang berasal dari bahasa Latin 'moderare', diartikan dengan tidak ekstrim, sedang dan bertentangan dengan sesuatu yang radikal. Ketika kata ini digandengkan dengan Islam, ada dua makna pokok yang tidak dapat dipisahkan, karena pemisahan keduanya akan menghasilkan pemahaman yang bertolak belakang.

Pertama, Islam moderat harus berangkat dari keyakinan bahwa Islam adalah agama moderat. Islam merupakan moderasi atau antitesis dari ekstrimitas agama sebelumnya. Islam merupakan jalan tengah dari dua versi ekstrim di atas dan memadukan "kehidupan bumi" dan "kehidupan langit". Itulah makna dari ummatan wasathan (umat pertengahan, pilihan dan adil).

Kedua, moderasi Islam di atas harus ditindaklanjuti dalam memahami dan menjalankan Islam dengan menjauhi sikap 'tatharruf' (ekstrim). Moderasi dalam Islam bermain di antara dua kutub ekstrim, yaitu overtekstualis dan overrasionalis. Overtekstualis akan mengerdilkan ruang ijtihad dan rasio sehingga menghasilkan kejumudan dan pengebirian akal, yang notabene merupakan karunia terbesar Allah. Sikap ini akan menyulitkan dinamisme-interaktif Islam dengan dunia yang terus berkembang dan modern. Pendekatan overrasionalis juga akan berbuah pahit karena akan melahirkan kenakalan rasionalitas terhadap teks dalam upaya "penyelarasan" Islam dengan dinamisme zaman.

Konsep Islam moderat bukan berarti sikap yang tidak berpihak kepada kebenaran serta tidak memiliki pendirian untuk menentukan mana yang haq dan bathil. Muslim moderat juga bukan orang munafik yang selalu cari aman, "plin-plan" dan memilihmilih ajaran Islam sesuai dengan kepentingannya. Muslim moderat berkeyakinan bahwa totalitas Islam merupakan agama yang selalu modern, tidak bermusuhan dengan dinamika dunia dan umat beragama lainnya.

Memahami Islam secara moderat, tidak radikal dan tidak liberal, tidak akan menghalangi penebaran rahmat yang sesungguhnya ke seluruh dunia. Islam moderat tetap mengusung konsep Islam semestinya tanpa ada yang dikurangi dan ditambahkan. Bedanya, pendekatan yang dilakukan lebih kontekstual dan rasional dalam bingkai kesantunan, keramahan dan kedamaian.

Rahmat Islam tidak hanya terletak pada keluhuran ajarannya (internal), tapi juga kesantunan dakwahnya (eksternal). Manusia 
mendapat rahmat Islam tidak hanya setelah masuk Islam, tapi sejak didatangi oleh dakwah Islam. Kalau memang diyakini bahwa Islam sesuai dengan fitrah setiap manusia, maka langkah selanjutnya adalah bagaimana membangunkan potensi fitrah setiap manusia itu. Kalau memang Islam benar secara rasional, pekerjaan berikutnya adalah mendidik rasionalitas manusia.

Karena itu, dakwah tidak perlu dengan kekerasan karena hanya akan menghasilkan keterpaksaan, sedang Allah tidak menerima orang yang tidak ikhlas. Dakwah juga tidak mungkin dengan sikap liberal karena hal itu akan melenyapkan berbagai sumber rahmat yang paling esensial bagi manusia.

(2) Model keagamaan toleran. Toleran berasal dari kata "tolerare" yang juga berasal dari bahasa latin yang berarti dengan sabar membiarkan sesuatu. Jadi pengertian toleransi secara luas adalah suatu sikap atau prilaku manusia yang tidak menyimpang dari aturan, dimana seseorang menghargai atau menghormati setiap tindakan yang orang lain lakukan.

Toleransi juga dapat dikatakan istilah dalam konteks sosial sosial budaya dan agama yang berarti sikap dan perbuatan yang melarang adanya diskriminasi terhadap kelompok-kelompok yang berbeda atau tidak dapat diterima oleh mayoritas dalam suatu masyarakat.

Kalau dihubungkan dengan agama, toleransi bisa dimaknai dengan dua hal; pertama secara internal, yaitu suatu sikap yang menghormati perbedaan pemahaman dan praktek keagaaman yang ada dalam satu agama. Atau secara eksternal, yaitu sikap sebagai umat yang beragama beragama dan mempunyai keyakinan untuk menghormati dan menghargai manusia yang beragama lain sehingga terbina kerukunan hidup.

Dari penjelasan sebelumnya bisa dipahami bahwa model keagamaan toleran adalah suatu sikap atau prilaku yang bisa memaklumi keberagamaan praktek dan pemikiran sosial-keagamaan yang berkembang di tengah-tengah masyarakat.

Tidak bersikap frontal yang mengandung arti tidak bertindak represif dalam menyikapi penomena sosial dan sistem nilai (kepercayaan) yang eksis baik dalam kehidupan masyarakat maupun dalam praktek kehidupan bernegara. Model keberagamaan seperti inilah sebenarnya yang pas untuk konteks Indonesia yang multi kultural.

\section{Kesimpulan}

Demikian gambaran sekelumit model keberagamaan Islam tradisionalis, sebagaimana disebutkan di atas yang 
sangat santun dan bijak dalam menyikapi setiap penomena sosial dan keagamaan yang berkembang dalam masyarakat. Berbeda dengan model Islam fundamentalis-pelebelan lain untuk puritanisme absolut- yang selalu menunjukkan wajah "garang" yang selalu melihat segala sesuatu dari sudut pandang hitam-putih tentu saja berdasarkan kreteria dan batasan yang mereka buat secara sepihak.

Kebenaran hanya berada di dalam wilayah penafsiran mereka yang dipandang sebagai hal yang mainstream. Sementara di luar penafsiran itu dianggap menyimpang atau sesat dan wajib untuk diperangi (jihad) tanpa alasan apapun. Akibatnya, terjadilah semacam sakeralisasi pemahaman yang dibangun atas dasar sentimen keagamaan yang berlebihan. Sehingga tidak ada ruang lagi bagi pemahaman keagamaan lainnya.

Akhir dari semua proses ini akan berujung pada pemaksaan kehendak dan penghakiman secara sepihak. Sampai disini, pertanyaannya adalah apakah kita akan mengubah wajah Islam yang santun dan toleran itu menjadi wajah Islam yang garang dan "menyeramkan"? Tentu saja hal itu tidak mungkin untuk dilakukan, karena secara naluriah manusia tidak suka dengan wajah yang garang.

Oleh sebab itu, mewariskan dan melestarikan wajah Islam yang manis dan damai merupakan tanggung jawab yang harus dikedepankan oleh setiap Individu Muslim. Model beragama seperti inilah yang akan memberikan citra dan masa depan yang baik bagi Islam. Wallah A'lam. 


\section{DAFTAR KEPUSTAKAAN}

Abdul Rahman Haji Abdullah, Pemikiran Islam di Malaysia, Sejarah dan Aliran, Jakarta: Gema Insani Press, 1977.

Abdurrahman Wahid, Islamku, Islam Anda, Islam Kita, Agama Masyarakat Negara Demokrasi, Jakarta: The Wahid Institute, 2006.

Ahamad Syafii Maarif, Islam dan Politik, Teori Belah Bambu, Masa Demokrasi Terpimpin (1959-1965), Jakarta: Gema Insani Press, 1996.

Alwi Shihab, Islam Sufistik: Islam Pertama dan Pengarubnya bingga Kini di Indonesia, Bandung: Mizan, 2001.

Amsal Bahtiar, Filsafat Agama, Wisata Pemikiran dan Kepercayaan Manusia, Jakarta: RajaGrafindo Persada, 2007.

Antony Reid, Sejarah Modern Awal Asia

Tenggara, Jakarta: LP3ES, 2004.

Arief Affandi, Islam, Demokrasi Atas Bawah: Polemik Perjuangan Umat Model Gus Dur dan Amien Rais, Yogyakarta: Pustaka Pelajar, 1996.

Asghar Ali Engineer, Islam Masa Kini, Yogyakarta: Pustaka Pelajar, 2004.

Azyumardi Azra, Renaisans Islam Asia Tenggara, Sejarah Wacana dan Kekuasaan, Bandung: Remaja Rosdakarya, 1999.
Jaringan Ulama Timur Tengah dan Kepulauan Nusantara Abad XVII dan XVIII, Bandung: Mizan, 1994.

Bahtiar Effendy, Teologi Baru Politik Islam, Pertautan Agama, Negara, dan Demokrasi, Yogyakarta: Galang Press, 2001.

Dedy Djamaluddin Malik, Idi Subandy Ibrahim, Zaman Baru Islam Indonesia, Pemikiran dan Aksi Politik, Bandung: Zaman Wacana Mulia 1998.

http://www.faithfreedom.org.

Hussin Mutalib, Islam and Etnicity in

Malay Politics, (terj), Jakarta:

LP3ES, 1996.

Ilham B. Saenong, Hermeneutika Pembebasan, Metodologi Tafsir AlQuran, Menurut Hasan Hanafi, Jakarta:Teraju, 2002.

Jalaludin Rahmat, Islam dan Pluralisme, Akblak Quran Menyikapi Perbedaan, Jakarta: Serambi Ilmu Semesta, 2006.

Koentjaraningrat, Pengantar Ilmu Antropologi, Jakarta: Rineka Cipta, 2002.

M.Quraish Shihab, Tafsir Al-Mishbah, Pesan, Kesan dan Keserasian AlQuran, Jakarta: Lentera Hati, 2000.

M.B. Hooker (Ed), Islam in South-East Asia, Leiden: E.J. Brill, 1983. 
Muhammad bin Abdul Wahab, Bersibkan Taubid Anda dari Noda Syirik, (terj), Surabaya: Bina Ilmu, Cet. 4, 1984

Muntaha Azhari dan Abdul Mun'in Saleh (Eds), Islam Indonesia Menatap Masa Depan, Jakarta: P3M, 1989.

Naquib Al-Attas, Islam dalam Sejarah dan Kebudayaan Melayu, Bandung: Mizan, Cet. 3, 1984.

Robert W. Hefner, Civil Islam, Islam dan Demokrasi di Indonesia, Yogyakarta: ISAI, 2001.

Said Aqil Siroj, Tasawuf sebagai Kritik Sosial, Bandung: Mizan, 2006.

Soerjono Soekanto, Sosiologi Suatu Pengantar, Jakarta: RajaGrafindo Persada, 2006.

Wahbah al-Zuhaili, Ushul al-Fiqh alIslamiy, Damaskus: Dar al-Fikr, Jilid 2, 2006. 